\title{
Monitoring of the Water Levels in the Wetlands of Fourmile Branch Near F-and H-Areas of SRS
}

by

K. L. Dixon

Westinghouse Savannah River Company

Savannah River Site

Aiken, South Carolina 29808

This paper was prepared in connection with work done under the above contract number with the $U$. S. Department of Energy. By acceptance of this paper, the publisher and/or recipient acknowledges the $U$. $S$. Government's right to retain a nonexclusive, royalty-free license in and to any copyright covering this paper, along with the right to reproduce and to authorize others to reproduce all or part of the copyrighted paper. 


\section{DISCLAIMER}

This report was prepared as an account of work sponsored by an agency of the United States Government. Neither the United States Government nor any agency thereof, nor any of their employees, makes any warranty, express or implied, or assumes any legal liability or responsibility for the accuracy, completeness, or usefulness of any information, apparatus, product, or process disclosed, or represents that its use would not infringe privately owned rights. Reference herein to any specific commercial product, process, or service by trade name, trademark, manufacturer, or otherwise does not necessarily constitute or imply its endorsement, recommendation, or favoring by the United States Government or any agency thereof. The views and opinions of authors expressed herein do not necessarily state or reflect those of the United States Government or any agency thereof.

This report has been reproduced directly from the best available copy.

Available to DOE and DOE contractors from the Office of Scientific and Technical Information, P. O. Box 62, Oak Ridge, TN 37831; prices available from (423) 576-8401.

Available to the public from the National Technical Information Service, U. S. Department of Commerce, 5285 Port Royal Road, Springfield, VA 22161. 
WSRC-TR-96-0289

$\operatorname{Rev} 0$

\section{Monitoring of the Water Levels in the Wetlands of Fourmile Branch Near the F- and H-Areas of SRS ${ }^{(U)}$}



Westinghouse Savannah River Company

Savannah River Site

Aiken, SC 29808

Prepared for the U.S. Department of Energy under contract no. DE-AC09-89SR18035 
Monitoring of the Water Levels in the Wetlands of Fourmile Branch Near the F- and H-Areas of SRS ${ }^{(U)}$

\author{
K. L. Dixon
}

Prepared for the U.S. Department of Energy under contract no. DE-AC09-89SR18035 


\title{
Monitoring of the Water Levels in the Wetlands of Fourmile Branch Near the F- and H-Areas of SRS
}

\author{
K. L. Dixon \\ Savannah River Technology Center \\ Westinghouse Savannah River Company \\ Aiken, SC 29802
}

\section{Executive Summary}

The South Carolina Department of Health and Environmental Control (SCDHEC) has issued a Resource Conservation and Recovery Act (RCRA) Hazardous Waste Part B Permit that prescribes a remediation approach for the groundwater in the F- and H-Area (Sadler, 1995). This approach calls for the installation of extraction and injection wells to capture and remediate the $10,000 \mathrm{pCi} / \mathrm{ml}$ tritium contaminant plume. Modeling of the groundwater remediation system suggests that wetland areas near Fourmile Branch may be impacted by reduced water levels. In order to assess potential impacts of the remediation effort on the riparian wetland system, a network of piezometers has been established. This network of piezometers has been established along the groundwater outcrop (i.e. seepline) for the water table aquifer, specifically targeting those areas closest to the extraction wells. The purpose of the piezometer network is to establish baseline hydraulic head data for the water table aquifer at the F- and $\mathrm{H}$-Area seeplines prior to startup of the groundwater extraction/injection remediation system.

A total of twenty piezometers were installed at fourteen different locations. Twelve piezometers were installed in F-Area, and eight were installed in H-Area. Following installation, monthly water level measurements have been taken from each piezometer, and are presented in this report.

Additionally, some piezometers have been instrumented with data loggers to allow for continuous monitoring of water levels. The purpose of continuous monitoring is to investigate the natural variability of water levels in the riparian wetland system of Fourmile Branch. Of particular interest is the variation in water levels associated with rainfall events, and evapotraspiration demand. The frequency, magnitude, and duration of these natural variations are unknown, and more frequent monitoring is required to assess them. Additionally, following startup of the extraction/injection system, increased variation in the hydrologic system in and around the wetlands is expected. These variations are expected to be more pronounced at those locations closest to the extraction wells. Thus, the piezometers closest to the extraction wells were chosen for instrumentation. The establishment of a baseline for the natural variations, as well as for the variations associated with the remediation system startup, will allow for the determination of an appropriate monitoring frequency for the remaining piezometers.

The information in this report was developed during the course of work under Contract No. DE-AC09-89SR 18035 with the U. S. Department of Energy. 


\section{Background}

Seepage basins in the F- and H-Areas of the Savannah River Site (SRS) received low-level radioactive waste effluent from the chemical separations processes in the General Separations Area. This waste effluent consisted mostly of sodium hydroxide, nitric acid, low levels of various radionuclides (primarily tritium), and some metals (Killian et al., 1985a and b). Discharges to the seepage basins were discontinued in 1988 and the basins were capped and sealed in 1990. As a result of basin operations, groundwater beneath and down gradient of the basins has been contaminated. The contamination is located primarily in the water table aquifer (Aquifer Zone $\mathrm{IIB}_{2}$ ) and in the Barnwell/McBean Aquifer (Aquifer Zone IIB $_{1}$ ). In both $\mathrm{F}$ - and $\mathrm{H}$-Area near the seepage basins, groundwater flow in Aquifer Zone $\mathrm{IIB}_{2}$ and $\mathrm{IIB}_{1}$ is towards Fourmile Branch. Aquifer Zone $\mathrm{IIB}_{2}$ discharges to the wetlands and Fourmile Branch while Aquifer Zone IIB $_{1}$ discharges primarily to Fourmile Branch. Contaminants originating from the seepage basins have been detected in shallow groundwater outcrops (i.e. the seepline) in the wetlands of Fourmile Branch in both F- and H-Area (Haselow et al., 1990; Dixon et al., 1993a; Dixon et al., 1993b, Dixon et al., 1994).

The South Carolina Department of Health and Environmental Control (SCDHEC) has issued a Resource Conservation and Recovery Act (RCRA) Hazardous Waste Part B Permit that prescribes a remediation approach for the groundwater in the F- and H-Area (Sadler, 1995). This approach calls for the installation of extraction and injection wells to capture and remediate the $10,000 \mathrm{pCi} / \mathrm{ml}$ tritium contaminant plume. Geotrans (1993) performed initial groundwater modeling for the F- and H-Area seepage basins to determine pumping rates for the extraction/injection well system; however, technical uncertainties were identified in the Geotrans model and a modeling effort was undertaken to resolve those uncertainties. Sadler (1995) has modified the Geotrans model for the groundwater at the F-Area seepage basin to include site specific data from recent aquifer tests, and has determined locations and pumping rates for the extraction/injection wells. A similar revised modeling exercise for the groundwater at the H-Area seepage basin is being conducted, but will not be finalized until the fall of 1996.

The remediation system in F-Area will consist of a total of seventeen wells within Aquifer Zone IIB $_{2}$; nine extraction and eight injection wells. The remediation system in $\mathrm{H}$-Area will consist of twenty three


Aquifer Zone $\mathrm{IIB}_{2}$ for the $\mathrm{F}$ - and $\mathrm{H}$-Area systems will be pumped at rates of $139 \mathrm{gpm}$ and $145 \mathrm{gpm}$, respectively. Currently, the remediation system for both $\mathrm{F}$ - and $\mathrm{H}$-Area is scheduled to begin operation in 1997 and is expected to operate over a period of 30 years.

Figures 1 and 2 show the proposed locations of the extraction/injection wells for the water table aquifer (Aquifer Zone $\mathrm{IIB}_{2}$ ) in F-Area and H-Area, respectively. The extraction wells are prefixed "FEX" and "HEX" and the injection wells are prefixed "FIN" and "HIN". Figure 3 shows the hydraulic head distribution for Aquifer Zone $\mathrm{IIB}_{2}$, for F-Area, and Figure 4 shows the simulated water level change for F-Area. It is evident from these two figures that there is potential for impact to the wetlands of Fourmile Branch near F-Area. Figure 4 shows a simulated drawdown of five feet at the seepline just south of the extraction well system. Lesser amounts of drawdown have been predicted for portions of the surrounding wetland areas. Because the revised modeling effort for the H-Area seepage basins has not been completed, figures depicting the hydraulic head distribution and simulated water level change were not available; however, the magnitude of changes in water level for Aquifer Zone IIB $_{2}$ in $\mathrm{H}$-Area are likely to be similar to those simulated for F-Area.

Decreases in water levels as great as those simulated by Sadler (1995) may result in drying of a portion of the wetlands, and an overall movement of the seepline towards Fourmile Branch. Chronic depression 
of the water table at the wetlands, and the associated reversal in direction of groundwater flow, may result in alterations of the wetland plant and animal communities in this area. Further, changes in the hydrology of the wetlands will have impacts on contaminant transport and on contaminant concentrations measured at the new seeplines.

To aid in assessing the impacts of the remediation system on the wetlands, changes in water levels in and near the wetlands must be monitored. Baseline hydraulic head data for the water table aquifer at both the F- and H-Area seeplines should be collected prior to initiation of groundwater extraction and should continue following startup. This information could prove to be critical in identifying the source of any wetland impacts that may be observed following startup of the extraction/injection system. To accomplish this, a network of piezometers has been established in the wetlands of Fourmile Branch in both F- and H-Areas. Currently, this network consists of twenty piezometers at fourteen different locations. The purpose of this report is to detail the installation of the piezometers, and to present the results of monthly water level measurements taken from them.

\section{METHODS}

\section{Piezometer Installation}

\section{"A" Series Piezometers}

Piezometer installation occurred in two phases. The initial phase of piezometer installation occurred in January 1996. A total of 14 piezometers were installed in the wetlands of Fourmile Branch near F- and $\mathrm{H}$-Areas: eight in the F-Area wetlands and six in the H-Area wetlands (Figure 1). These piezometers have been designated the " $\mathrm{A}$ " series piezometers, and were all screened within Aquifer Zone $\mathrm{IIB}_{2}$ (water table). The piezometers were installed in a network in both $\mathrm{F}$ - and H-Area outlining the current seepline focusing on those areas predicted to be most impacted by groundwater extraction.

With the exception of FPZ003A, all piezometers were installed using hand augering equipment ( 3 1/4" bucket auger) according to WSRC-3Q5 (Chapter 7) procedures. Hand augering was chosen as the method of installation to minimize disturbance of the wetland areas. Location FPZ003A is in an upland area. Due to the depth to the water table at this location, it was installed using hollow stem augering techniques.

Installation depth varied from location to location based upon local stratigraphy, and the depth to the water table as observed during installation. For the " $A$ " series piezometers, the goal was to install each piezometer to the maximum depth achievable using hand augering techniques. This afforded the opportunity to view the stratigraphy, and detect the presence of any clay layers which might be considered local confining layers. In the presence of these clay layers, every effort was made to auger through and screen in the material beneath the layer; however, at some locations, clay layers were encountered at depths impractical to auger through with a hand auger (i.e. at 15 to $20 \mathrm{ft} \mathrm{bgs}$ ). At these locations, the piezometers were screened on top of the clay layer.

Each piezometer was constructed of 2-inch diameter PVC TriLok@ material and screened with TriLok@ well screens ( 0.010 inch slot size). Surface casing (4" diameter PVC) was used at each location (except FPZ003A) to prevent hole collapse during augering. Generally, at each location, the borehole was augered until unconsolidated material was encountered, and the surface casing then driven through the unconsolidated zone. The surface casing was left in-place following piezometer installation to provide protection from animal damage, and to further enhance the surface seal. The length of screen installed at each location depended on the heterogeneity observed in the stratigraphy at that location. In most cases, 
screen lengths were $2.5 \mathrm{ft}$; however, at some locations with relatively homogenous stratigraphy, $5 \mathrm{ft}$ screens were installed. Except at locations where piezometers were installed in unconsolidated material (i.e. flowing sands), a sand filter pack was installed to about $1 \mathrm{ft}$ above the screen. At locations screened in unconsolidated material, hole collapse prevented installation of the standard filter pack; however, at least $1 \mathrm{ft}$ of sand was installed on top of the collapsed material as a buffer between the natural material and the bentonite seal. After installation of the filter pack, each borehole was filled to within $1 \mathrm{ft}$ of the ground surface with bentonite for sealing purposes. All piezometers were developed using a hand bailer according to WSRC-3Q5 (Chapter 7) procedures.

Table 1 gives the piezometer construction information for each location. Included in this table for all piezometers are the coordinates, ground elevation, top of casing elevation, length of casing stickup, total augered depth, screened length, screen slot size, top of screen elevation, sump length, sump cap length, and bottom elevation of the piezometer.

\section{B Series Piezometers}

The second phase of piezometer installation occurred in May 1996. A total of 6 additional piezometers were installed in the wetlands of Fourmile Branch near F- and H-Areas: four in the F-Area wetlands and two in the H-Area wetlands (Figure 1). These piezometers have been designated the "B" series piezometers, and were all screened within Aquifer Zone $\mathrm{IIB}_{2}$ (water table). These piezometers were installed at locations identified during the initial phase of installation as having relatively heterogeneous stratigraphy, and were screened at shallower depths than the "A" series piezometers. Generally, "B" series piezometers were installed at locations where " $\mathrm{A}$ " series piezometers were installed beneath significant clay layers.

Installation procedures for the " $\mathrm{B}$ " series piezometers were essentially the same as for the " $\mathrm{A}$ " series piezometers installed during January 1996. The "B" series piezometers were screened from just below the ground surface through the entire depth of installation. At each location, a sand filter pack was installed to about $1 \mathrm{ft}$ below the ground surface. The remainder of the borehole was filled with bentonite for sealing purposes. All piezometers were developed using a hand bailer according to WSRC-3Q5 (Chapter 7) procedures. Table 1 gives the piezometer construction information for the " $B$ " series piezometers.

\section{Measurement of Water Levels}

Water levels in the piezometers are measured manually on a monthly basis using an electric water level tape. From these measurements, the elevation of the water table is determined for each location. Additionally, the water level of Fourmile Branch is measured at two locations. These two stream sites are located where Fourmile Branch crosses Road C4 and Road E1.

\section{Instrumentation of Selected Piezometers}

In an effort to investigate the natural variability of water levels in the riparian wetland system of Fourmile Branch, several piezometers have been instrumented with data logging equipment to allow for continuous water level monitoring. Of particular interest is the variation in water levels associated with rainfall events, and evapotraspiration demand. The frequency, magnitude, and duration of these natural variations are unknown, and more frequent monitoring is required to assess them. Additionally, following startup of the extraction/injection system, increased variation in the hydrologic system in and around the wetlands is expected. These variations are expected to be more pronounced at those locations 
closest to the extraction wells. Thus, the piezometers closest to the extraction wells were chosen for instrumentation. The establishment of a baseline for the natural variations, as well as for the variations associated with the remediation system startup, will allow for the determination of an appropriate monitoring frequency for the remaining piezometers.

The piezometers selected for instrumentation are shown in Figures 1 and 2, and are listed in Table 2. Table 2 also gives the date of instrumentation for each piezometer. Each of the selected piezometers was equipped with a pressure transducer ( 5 psig range) controlled by a Campbell Scientific, Inc. CR 10X data logger. Additionally, at locations FPZ005A and HPZ003A, a tipping bucket rain gage was connected to the CR10X to provide rainfall data.

Water level measurements are monitored continuously at each location and averaged every thirty minutes. Additionally, rainfall amounts are totaled every thirty minutes for both $\mathrm{F}$ - and $\mathrm{H}$-Areas.

\section{Discussion}

Results from the monthly water level measurements for the period of January 1996 through August 1996 are presented in Table 3 . The minimum, maximum, and average water level elevation, and standard deviation was computed for each location and is presented in Table 4. Table 4 also gives the average water level in each piezometer relative to ground elevation.

Preliminary evaluation of data collected from the continuous monitoring effort has revealed an obvious correlation between rainfall events and water levels in the wetlands. Figures 5 and 6 represent typical plots of data collected from the piezometers. From these figures, it can be seen that the response to rainfall is immediate as well as transient; however, more detailed study over a longer period of time is needed to determine the magnitude and duration of the transient surge in water levels associated with rainfall.

In addition to the rainfall response, diurnal fluctuations in water level due to evapotranspiration are also clearly shown in Figures 5 and 6. A periodic decline in water levels is observed during the middle portions of each day, which may be attributed to increased evapotranspiration demand. During the nighttime hours when evapotranspiration demands are lowest, the water levels recover. As seen in Figure 5 , fluctuations of $0.1 \mathrm{ft}$ are not uncommon during peak evapotranspiration periods:

Figures 5 and 6 demonstrate the natural variability in water levels in the wetlands of Fourmile Branch. In order to completely define baseline conditions for the wetlands, the magnitude, frequency, and duration of the variations must be quantified. Long term assessment of data collected from the instrumented piezometers will allow for a more detailed analysis of the natural variations associated with these types of iwetland systems. 


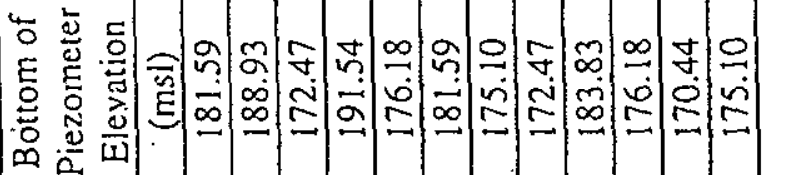



劳 过范

n

ธิ 엥

焉 ปั

恶

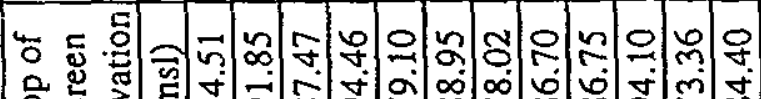

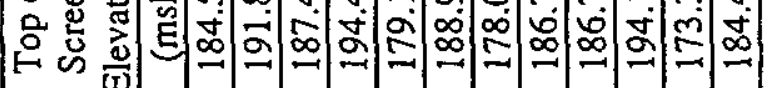

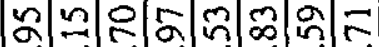

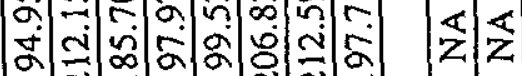

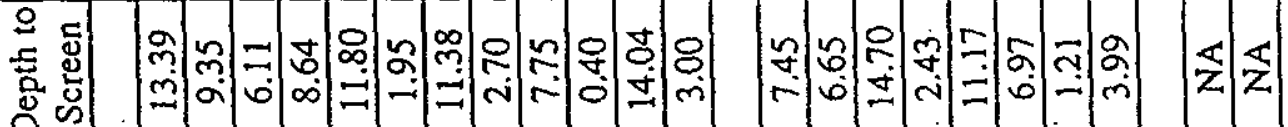

荌

45

푼 올

总 总

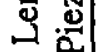

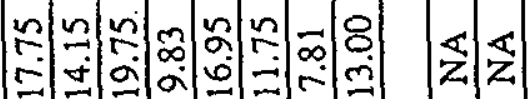

을

:

宓

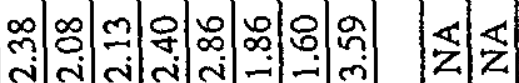

$\stackrel{2}{5}$

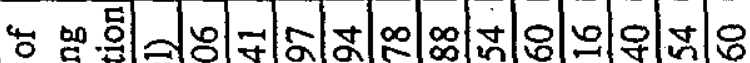

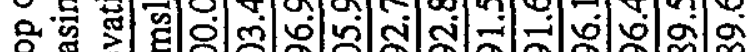

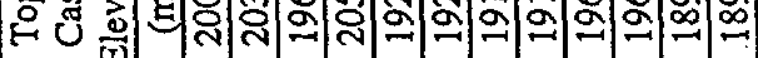

$\infty \infty m \infty$ 舟

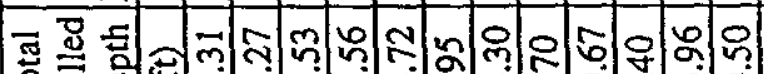

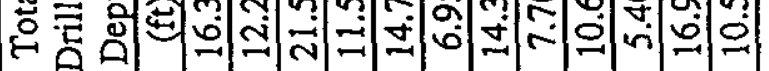

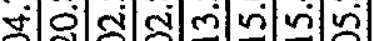

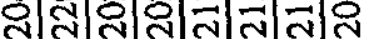

它

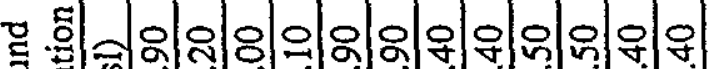

它

m

E

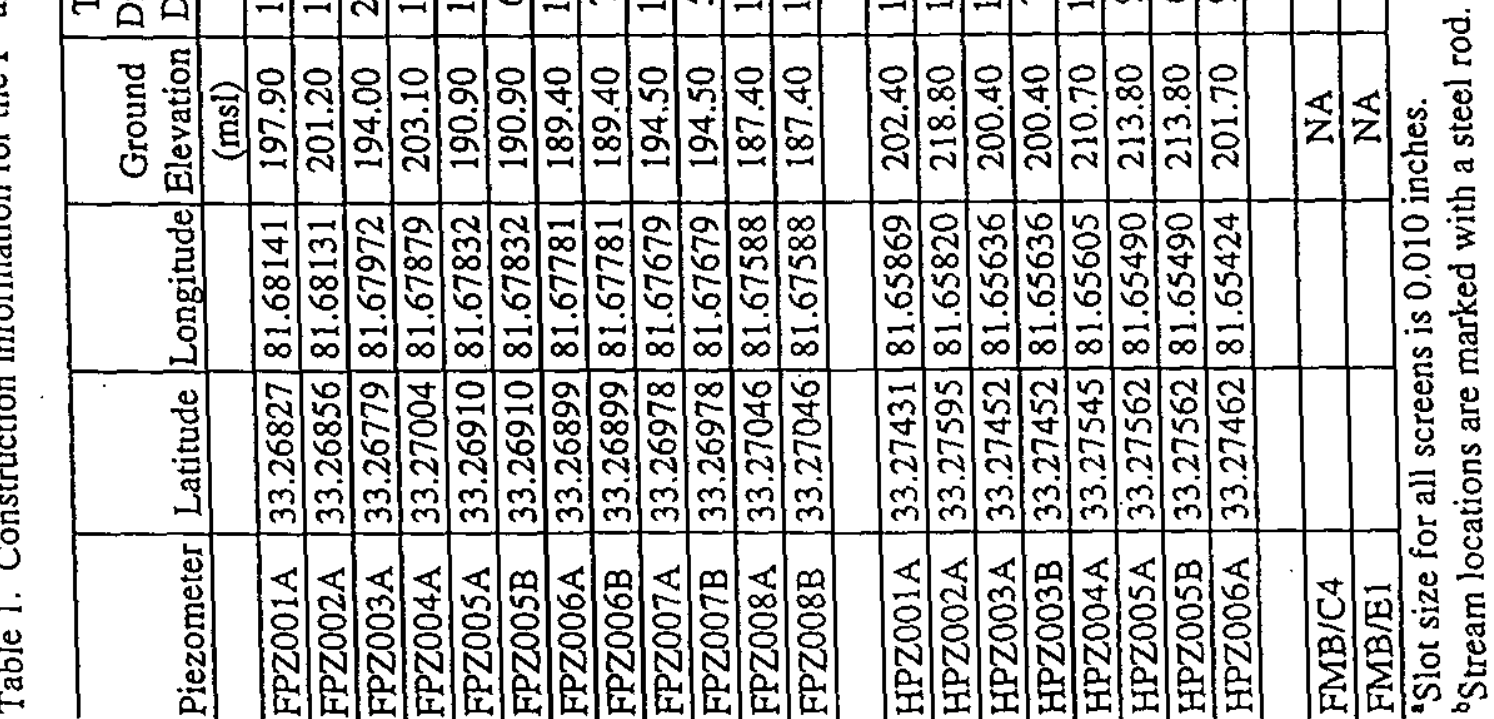


Table 2. Piezometers with data logging equipment installed.

\begin{tabular}{l|c|c|c}
\hline Piezometer & Latitude & Longitude & Instrumentation Date \\
\hline FPZ001A & 33.26827 & 81.68141 & September 1996 \\
\hline FPZ002A & 33.26856 & 81.68131 & September 1996 \\
\hline FPZ004A & 33.27004 & 81.67879 & July 1996 \\
\hline FPZ005A & 33.26910 & 81.67832 & July 1996 \\
\hline FPZ006A & 33.26899 & 81.67781 & July 1996 \\
\hline & & & \\
\hline HPZ002A & 33.27595 & 81.65820 & September 1996 \\
\hline HPZ003A & 33.27452 & 81.65636 & August 1996 \\
\hline HPZ004A & 33.27545 & 81.65605 & August 1996 \\
\hline HPZ005A & 33.27562 & 81.65490 & September 1996 \\
\hline
\end{tabular}


Table 3. Monthly Water Level Measurements.

\begin{tabular}{l|c|c|c|c|c|c|c|c|c}
\hline $\begin{array}{l}\text { Piezometer } \\
\text { ID }\end{array}$ & \multicolumn{7}{|c|}{$\begin{array}{c}\text { Water Level Elevations } \\
\text { (msl) }\end{array}$} & $\begin{array}{c}\text { Ground } \\
\text { Elevation } \\
\text { (ms) }\end{array}$ \\
\hline & Jan-96 & Feb-96 & Mar-96 & Apr-96 & May-96 & Jun-96 & Jul-96 & Aug-96 & \\
\hline FPZ001A & 198.01 & 198.00 & 197.99 & 197.98 & 197.94 & 197.96 & 197.96 & 198.02 & 197.90 \\
\hline FPZ002A & 201.65 & 201.47 & 201.83 & 201.60 & 201.36 & 201.35 & 201.23 & 201.80 & 201.20 \\
\hline FPZ003A & 189.52 & 189.11 & 190.41 & 188.87 & 187.35 & 187.96 & 187.07 & 190.15 & 194.00 \\
\hline FPZ004A & 201.59 & 201.42 & 201.72 & 201.59 & 201.36 & 201.35 & 201.26 & 201.57 & 203.10 \\
\hline FPZ005A & 191.23 & 191.24 & 191.26 & 191.19 & 191.08 & 191.12 & 191.13 & 191.18 & 190.90 \\
\hline FPZ005B & ND & ND & ND & ND & ND & 191.22 & 191.23 & 191.18 & 190.90 \\
\hline FPZ006A & 189.49 & 189.35 & 189.56 & 189.19 & 188.60 & 188.84 & 188.99 & 189.34 & 189.40 \\
\hline FPZ006B & ND & ND & ND & ND & ND & 188.50 & 188.87 & 189.04 & 189.40 \\
\hline FPZ007A & 193.19 & 193.04 & 193.20 & 192.96 & 192.66 & 192.83 & 192.94 & 193.12 & 194.50 \\
\hline FPZ007B & ND & ND & ND & ND & ND & 194.28 & 193.83 & 194.33 & 194.50 \\
\hline FPZ008A & 187.70 & 187.67 & 187.72 & 187.65 & 187.56 & 187.58 & 187.59 & 187.63 & 187.40 \\
\hline FPZ008B & ND & ND & ND & ND & ND & 187.55 & 187.58 & 187.59 & 187.40 \\
\hline & & & & & & & & & \\
\hline HPZ001A & 202.37 & 202.35 & 202.36 & 202.35 & 202.05 & 202.23 & 202.25 & 202.30 & 202.40 \\
\hline HPZ002A & 218.58 & 218.40 & 218.89 & 218.69 & 218.17 & 218.00 & 217.93 & 218.50 & 218.80 \\
\hline HPZ003A & 199.07 & 201.11 & 201.23 & 201.01 & 200.42 & 200.81 & 201.23 & 201.26 & 200.40 \\
\hline HPZ003B & ND & ND & ND & ND & ND & 200.39 & 200.74 & 201.02 & 200.40 \\
\hline HPZ004A & 210.36 & 210.30 & 210.38 & 210.30 & 210.11 & 210.11 & 208.88 & 210.30 & 210.70 \\
\hline HPZ005A & 213.21 & 212.79 & 213.25 & 212.51 & 211.61 & 211.99 & 212.46 & 213.06 & 213.80 \\
\hline HPZ005B & ND & ND & ND & ND & ND & 211.91 & 213.75 & 213.05 & 213.80 \\
\hline HPZ006A & 201.77 & 201.74 & 201.78 & 201.70 & 201.53 & 201.76 & 201.83 & 202.09 & 201.70 \\
\hline & & & & & & & & & \\
\hline FMB/E1 & ND & 214.56 & 214.70 & 214.60 & 214.37 & 214.41 & 214.30 & 214.47 & NA \\
\hline
\end{tabular}


Table 4. Average Water Level Measurements for the Period of January 1996 to August 1996.

\begin{tabular}{|c|c|c|c|c|c|}
\hline $\begin{array}{l}\text { Piezometer } \\
\text { ID }\end{array}$ & $\begin{array}{c}\text { Minimum Water } \\
\text { Level }\end{array}$ & $\begin{array}{c}\text { Maximum Water } \\
\text { Level } \\
\end{array}$ & $\begin{array}{c}\text { Average Water } \\
\text { Level }\end{array}$ & Standard Deviation & $\begin{array}{c}\text { Water Level } \\
\text { Relative to Ground } \\
\text { Elevation }\end{array}$ \\
\hline & $(\mathrm{msl})$ & $(\mathrm{msl})$ & $(\mathrm{msl})$ & $(\mathrm{ft})$ & $(\mathrm{ft})$ \\
\hline FPZ001A & 197.94 & 198.02 & 197.98 & 0.03 & 0.08 \\
\hline FPZ002A & 201.23 & 201.83 & 201.54 & 0.22 & 0.34 \\
\hline FPZ003A & 187.07 & 190.41 & 188.81 & 1.24 & -5.19 \\
\hline FPZ004A & 201.26 & 201.72 & 201.48 & 0.16 & -1.62 \\
\hline FPZ005A & 191.08 & 191.26 & 191.18 & 0.06 & 0.28 \\
\hline FPZ005B & 191.18 & 191.23 & 191.21 & 0.03 & 0.31 \\
\hline FPZ006A & 188.60 & 189.56 & 189.17 & 0.33 & -0.23 \\
\hline FPZ006B & 188.50 & 189.04 & 188.80 & 0.28 & -0.60 \\
\hline FPZ007A & 192.66 & 193.20 & 192.99 & 0.19 & -1.51 \\
\hline FPZ007B & 193.83 & 194.33 & 194.15 & 0.28 & -0.35 \\
\hline FPZ008A & 187.56 & 187.72 & 187.64 & 0.06 & 0.24 \\
\hline FPZ008B & 187.55 & 187.59 & 187.57 & 0.02 & 0.17 \\
\hline HPZ001A & 202.05 & 202.37 & 202.28 & 0.11 & -0.12 \\
\hline HPZ002A & 217.93 & 218.89 & 218.40 & 0.34 & -0.41 \\
\hline HPZ003A & 199.07 & 201.26 & 200.77 & 0.74 & 0.37 \\
\hline HPZO03B & 200.39 & 201.02 & 200.72 & 0.32 & 0.32 \\
\hline HPZ004A & 208.88 & 210.38 & 210.09 & 0.50 & -0.61 \\
\hline HPZ005A & 211.61 & 213.25 & 212.61 & 0.59 & -1.19 \\
\hline HPZ00SB & 211.91 & 213.75 & 212.90 & 0.93 & -0.90 \\
\hline $\mathrm{HPZ} 006 \mathrm{~A}$ & 201.53 & 202.09 & 201.78 & 0.16 & 0.07 \\
\hline$\overline{\mathrm{FMB} / \mathrm{C} 4}$ & 178.18 & 178.42 & 178.29 & 0.10 & NA \\
\hline FMB/E1 & 214.30 & 214.70 & 214.49 & 0.14 & NA \\
\hline
\end{tabular}

"Positive values indicate the water level is above ground elevation. Negative

values indicate the water level is below ground elevation. 


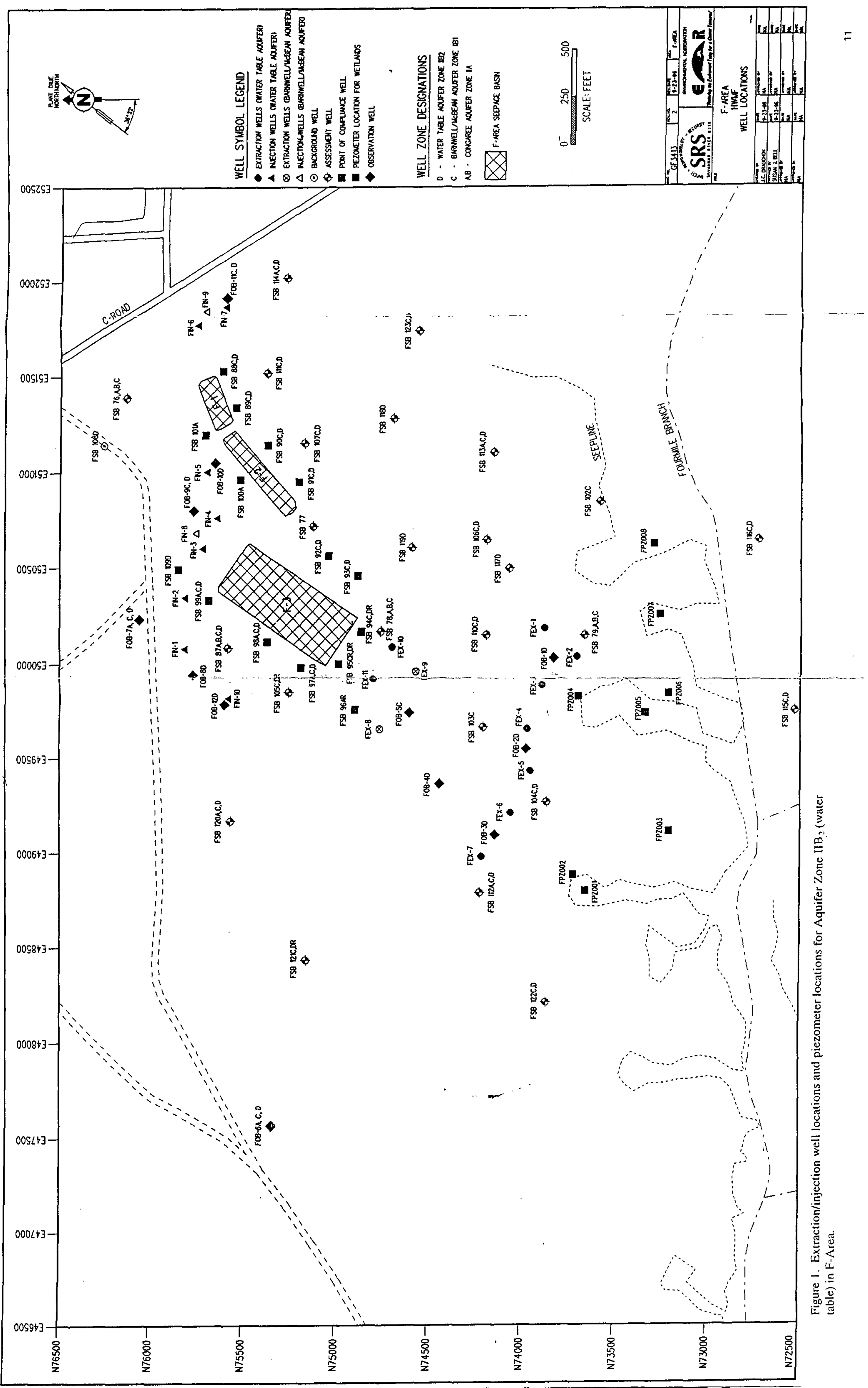




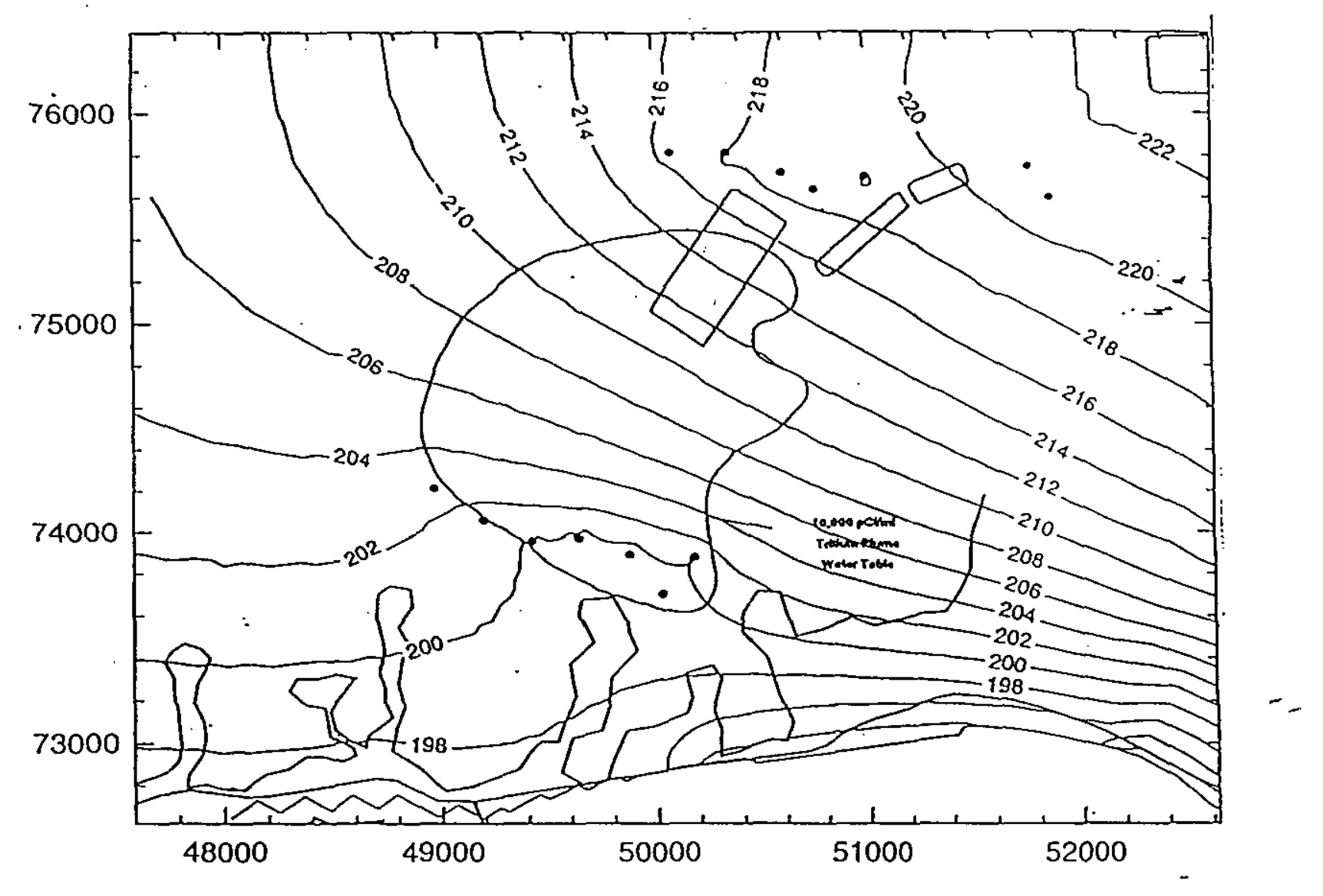

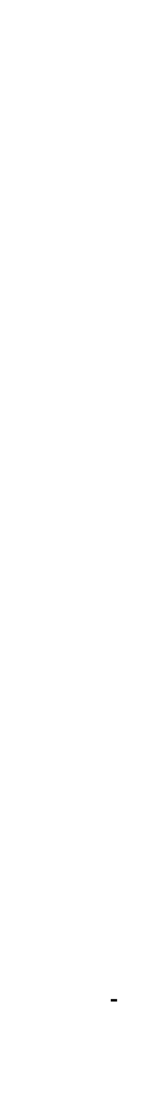

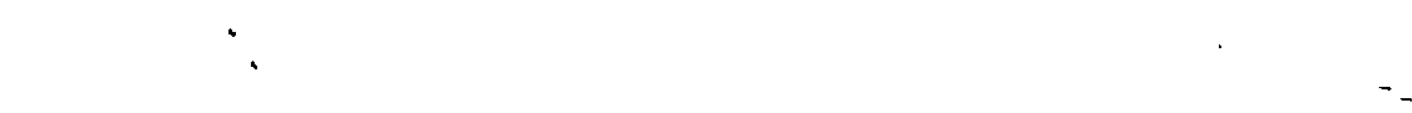

Figure 3. Hydraulic head distribution for Aquifer Zone $\mathrm{IIB}_{2}$ (water table) in F-Area simulated for the proposed extraction/injection well system (taken from Sadler, 1995). 


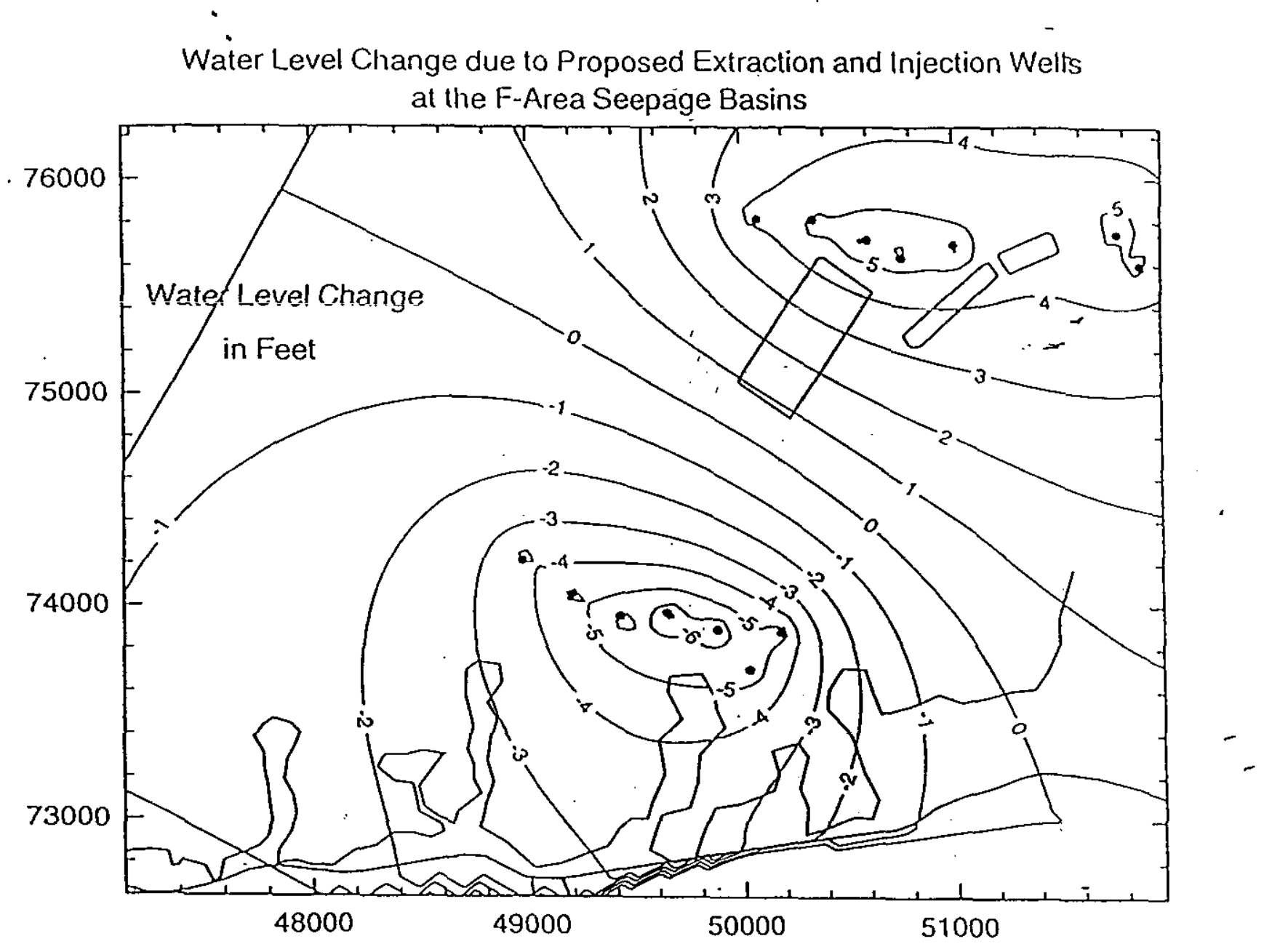

Figure 4. Water level change for Aquifer Zone $\mathrm{IIB}_{2}$ (water table) in F-Area simulated for the proposed extraction/injection well system (Sadler, 1995). 




Figure 5. Continuous water level measurements taken from FPZ004A.

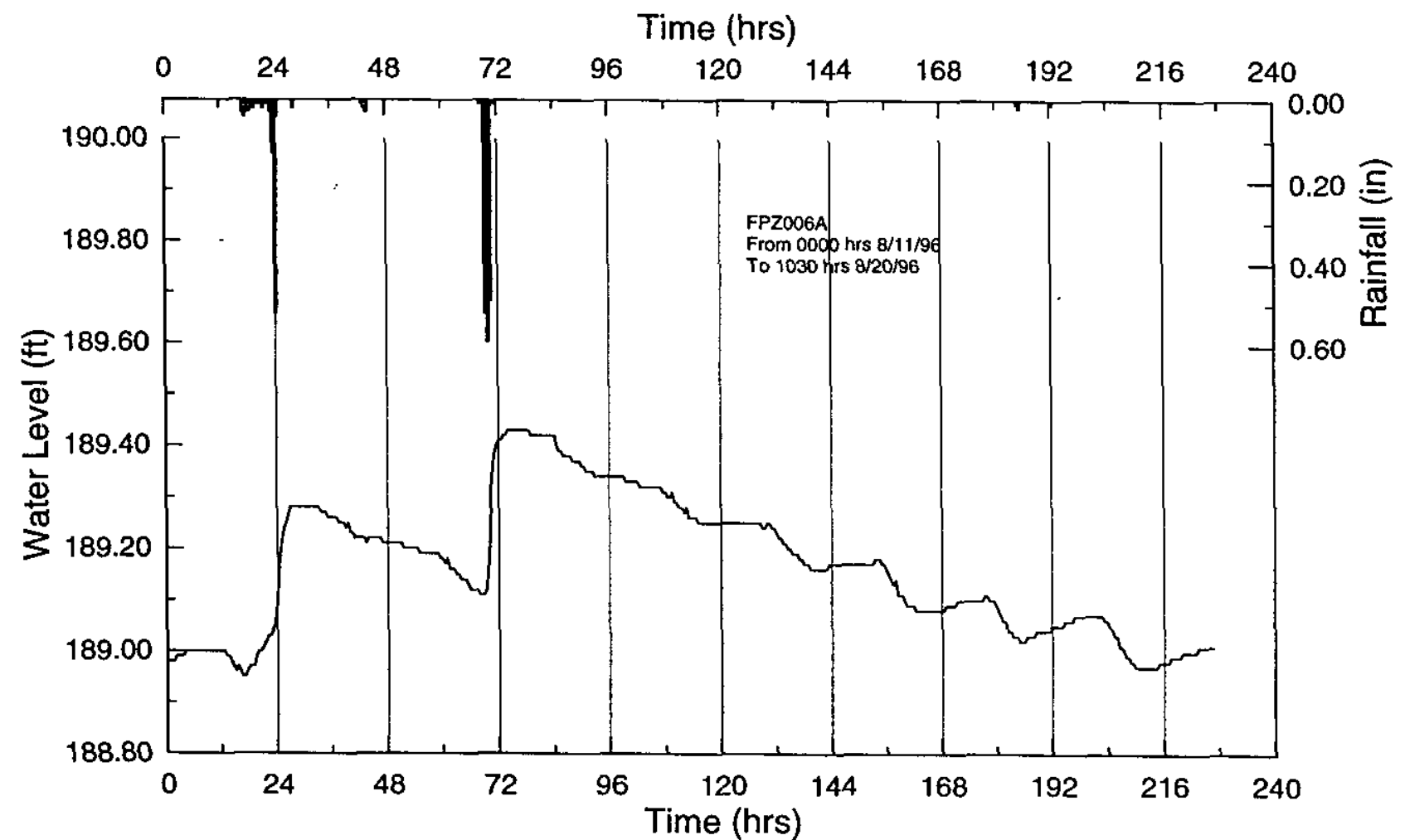

Figure 6. Continuous water level measurements taken from FPZ006A. 


\section{References}

Dixon, K. L., V. A. Rogers, and B. B. Looney. 1993a. Results of the quarterly tritium survey of Four Mile Creek and its seeplines in the F- and H- Areas of SRS: September 1993. WSRC-TR-93-286-E, Rev. 1, Westinghouse Savannah River Company, Savannah River Technology Center, Aiken SC.

Dixon, K. L. and V. A. Rogers. 1993b. Semi-annual sampling of Fourmile Branch and its seeplines in the F- and H-Areas of SRS: July 1992. WSRC-TR-93-289, Westinghouse Savannah River Company, Savannah River Technology Center, Aiken SC.

Geotrans, Inc. 1993. Groundwater model calibration and review of remedial alternatives at the F- and HArea seepage basins. WSRC-TR-93-384, Westinghouse Savannah River Company, Aiken SC.

Haselow, J. S., M. Harris, B. B. Looney, N. V. Halverson, and J. B. Gladden. 1990. Analysis of soil and water at the Four Mile Creek seepline near the F- and H-Areas of SRS. WSRC-RP-90-0591, Westinghouse Savannah River Company, Savannah River Technology Center, Aiken SC.

Killian, T.H., N.L. Kolb, P. Corbo, and I.W. Marine. 1985a. F-Area seepage basins. DPST-85-704, E.I. du Pont de Nemours and Company, Savannah River Laboratory, Aiken, SC.

Killian, T.H., N.L. Kolb, P. Corbo, and I.W. Marine. 1985b. H-Area seepage basins. DPST-85-706, E.I. du Pont de Nemours and Company, Savannah River Laboratory, Aiken, SC.

Sadler, W.R. 1995. Groundwater model recalibration and remediation well network design at the F-Area seepage basins. WSRC-RP-95-237, Westinghouse Savannah River Company, Site Geotechnical Services Department, Aiken, SC. 